\title{
Napoleon Bonaparte: His Successes and Failures
}

\begin{abstract}
Zakia Sultana
Assist. Prof., School of Liberal Arts and Social Sciences, University of Information Technology and Sciences (UITS), Baridhara, Dhaka, Bangladesh
\end{abstract}

\begin{abstract}
Napoleon Bonaparte (1769-1821), also known as Napoleon I, was a French military leader and emperor who conquered much of Europe in the early 19th century. Born on the island of Corsica, Napoleon rapidly rose through the ranks of the military during the French Revolution (1789-1799). After seizing political power in France in a 1799 coup d'état, he crowned himself emperor in 1804. Shrewd, ambitious and a skilled military strategist, Napoleon successfully waged war against various coalitions of European nations and expanded his empire. However, after a disastrous French invasion of Russia in 1812, Napoleon abdicated the throne two years later and was exiled to the island of Elba. In 1815 , he briefly returned to power in his Hundred Days campaign. After a crushing defeat at the Battle of Waterloo, he abdicated once again and was exiled to the remote island of Saint Helena, where he died at 51.Napoleon was responsible for spreading the values of the French Revolution to other countries, especially in legal reform and the abolition of serfdom. After the fall of Napoleon, not only was the Napoleonic Code retained by conquered countries including the Netherlands, Belgium, parts of Italy and Germany, but has been used as the basis of certain parts of law outside Europe including the Dominican Republic, the US state of Louisiana and the Canadian province of Quebec. The memory of Napoleon in Poland is favorable, for his support for independence and opposition to Russia, his legal code, the abolition of serfdom, and the introduction of modern middle class bureaucracies. The social structure of France changed little under the First Empire. It remained roughly what the Revolution had made it: a great mass of peasants comprising three-fourths of the population-about half of them works owners of their farms or sharecroppers and the other half with too little land for their own subsistence and hiring themselves out as laborers. Industry, stimulated by the war and the blockade of English goods, made remarkable progress in northern and eastern France, whence exports could be sent to central Europe; but it declined in the south and west because of the closing of the Mediterranean and the Atlantic. The great migrations from rural areas toward industry in the towns began only after 1815. The nobility would probably have declined more swiftly if Napoleon had not restored it, but it could never recover its former privileges. Finally we can say that many of the territories occupied by Napoleon during his Empire began to feel a new sense of nationalism.
\end{abstract}

Keywords: Military power, Brumaire, Abdication, War, Napoleonic Code, Metric system, Continental system, Campaign, Nationalism

\section{Introduction}

In the book 'The Rise of Napoleon Bonaparte' by Robert Asprey opined from the report of Nepoleon's examiner (École Militaire, Paris, August 1785) that "...reserved and studious, he prefers study to any type of amusement, finding pleasure is the reading of good authors; very applied [to the study of] abstract sciences, little curious as the others,[having] a thorough knowledge of mathematics and geography; quiet, loving solitude, capricious, arrogant, extremely inclined to egoism, speaking little spirited in his answers, quick and harsh in his replies having much pride and boundless ambition, this young man deserves to be encouraged." Napoleon Bonaparte (1769-1821), also known as Napoleon I, was a French military leader and emperor who conquered much of Europe in the early 19th century. Born on the island of Corsica, Napoleon rapidly rose through the ranks of the military during the French Revolution (1789-1799). After seizing political power in France in a 1799 coup d'état, he crowned himself emperor in 1804. Shrewd, ambitious and a skilled military strategist, Napoleon successfully waged war against various coalitions of European nations and expanded his empire. However, after a disastrous French invasion of Russia in 1812, Napoleon abdicated the throne two years later and was exiled to the island 
of Elba. In 1815, he briefly returned to power in his Hundred Days campaign. After a crushing defeat at the Battle of Waterloo, he abdicated once again and was exiled to the remote island of Saint Helena, where he died at 51. [1]

\section{Napoleon's Education and Early Military Career}

Napoleon Bonaparte was born on August 15, 1769, in Ajaccio, on the Mediterranean island of Corsica. He was the second of eight surviving children born to Carlo Buonaparte (1746-1785), a lawyer, and Letizia Romalino Buonaparte (1750-1836). Although his parents were members of the minor Corsican nobility, the family was not wealthy. The year before Napoleon's birth, France acquired Corsica from the city-state of Genoa, Italy. Napoleon later adopted a French spelling of his last name.

In 1799, during Napoleon's military campaign in Egypt, a French soldier named Pierre Francois Bouchard (1772-1832) discovered the Rosetta Stone. This artifact provided the key to cracking the code of Egyptian hieroglyphics, a written language that had been dead for almost 2,000 years.

As a boy, Napoleon attended school in mainland France, where he learned the French language, and went on to graduate from a French military academy in 1785 . He then became a second lieutenant in an artillery regiment of the French army. The French Revolution [2] began in 1789, and within three years revolutionaries had overthrown the monarchy and proclaimed a French republic. During the early years of the revolution, Napoleon was largely on leave from the military and home in Corsica, where he became affiliated with the Jacobins, a pro-democracy political group. In 1793, following a clash with the nationalist Corsican governor, Pasquale Paoli (1725-1807), the Bonaparte family fled their native island for mainland France, where Napoleon returned to military duty.

In France, Napoleon became associated with Augustin Robespierre (1763-1794), the brother of revolutionary leader Maximilien Robespierre (1758-1794), a Jacobin who was a key force behind the Reign of Terror (1793-1794),[3] a period of violence against enemies of the revolution. During this time, Napoleon was promoted to the rank of brigadier general in the army. However, after Robespierre fell from power and was guillotined (along with Augustin) in July 1794, Napoleon was briefly put under house arrest for his ties to the brothers. 2 In 1795 , Napoleon helped suppress a royalist insurrection against the revolutionary government in Paris and was promoted to major general.

\section{Napoleon's Rise to Power}

Since 1792, France's revolutionary government had been engaged in military conflicts with various European nations. In 1796, Napoleon commanded a French army that defeated the larger armies of Austria, one of his country's primary rivals, in a series of battles in Italy. In 1797, France and Austria signed the Treaty of Campo Formio, resulting in territorial gains for the French.

The following year, the Directory, the five-person group that had governed France since 1795, offered to let Napoleon lead an invasion of England. Napoleon determined that France's naval forces were not yet ready to go up against the superior British Royal Navy. Instead, he proposed an invasion of Egypt in an effort to wipe out British trade routes with India. Napoleon's troops scored a victory against Egypt's military rulers, the Mamluks, at the Battle of the Pyramids [4] in July 1798; soon, however, his forces were stranded after his naval fleet was nearly decimated by the British at the Battle of the Nile in August 1798. In early 1799, Napoleon's army launched an invasion of Ottoman-ruled Syria, which ended with the failed siege of Acre, located in modern-day Israel. That summer, with the political situation in France marked by uncertainty, the ever-ambitious and cunning Napoleon opted to abandon his army in Egypt and return to France.

\section{The Coup of 18 Brumaire}

In November 1799, in an event known as the coup of 18 Brumaire, [5] Napoleon was part of a group that successfully overthrew the French Directory. The Directory was replaced with a three-member Consulate, and Napoleon became first consul, making him France's leading political figure. In June 1800, at the Battle of Marengo, Napoleon's forces defeated one of France's perennial enemies, the Austrians, and drove them out of Italy. The victory helped cement Napoleon's power as first consul. Additionally, with the Treaty of Amiens in 1802, the war-weary British agreed to peace with the French (although the peace would only last for a year).

In 1802, a constitutional amendment made Napoleon first consul for life. Two years later, in 1804, he crowned himself emperor of France in a lavish ceremony at the Cathedral of Notre Dame in Paris. 


\section{Napoleon's Marriages and Children}

In 1796, Napoleon married Josephine de Beauharnais (1763-1814), a stylish widow six years his senior who had two teenage children. More than a decade later, in 1809, after Napoleon had no offspring of his own with Josephine, he had their marriage annulled so he could find a new wife and produce an heir. In 1810, he wed Marie Louise (1791-1847), the daughter of the emperor of Austria. The following year, she gave birth to their son, Napoleon François Joseph Charles Bonaparte (1811-1832), who became known as Napoleon II and was given the title king of Rome. In addition to his son with Marie Louise, Napoleon had several illegitimate children.

\section{The Reign of Napoleon}

From 1803 to 1815, France was engaged in the Napoleonic Wars, a series of major conflicts with various coalitions of European nations. In 1803, partly as a means to raise funds for future wars, Napoleon sold France's Louisiana Territory in North America to the newly independent United States for $\$ 15$ million, a transaction that later became known as the Louisiana Purchase [6].

In October 1805, the British wiped out Napoleon's fleet at the Battle of Trafalgar [7]. However, in December of that same year, Napoleon achieved what is considered to be one of his greatest victories at the Battle of Austerlitz, in which his army defeated the Austrians and Russians. The victory resulted in the dissolution of the Holy Roman Empire and the creation of the Confederation of the Rhine.

Beginning in 1806, Napoleon sought to wage large-scale economic warfare against Britain with the establishment of the so-called Continental System of European port blockades against British trade. In 1807, following Napoleon's defeat of the Russians at Friedland in Prussia, Alexander I (1777-1825) was forced to sign a peace settlement, the Treaty of Tilsit. In 1809 , the French defeated the Austrians at the Battle of Wagram, resulting in further gains for Napoleon.

During these years, Napoleon reestablished a French aristocracy (eliminated in the French Revolution) and began handing out titles of nobility to his loyal friends and family as his empire continued to expand across much of western and central continental Europe.

\section{Napoleon's Downfall and First Abdication}

In 1810, Russia withdrew from the Continental System. In retaliation, Napoleon led a massive army into Russia in the summer of 1812. Rather than engaging the French in a full-scale battle, the Russians adopted a strategy of retreating whenever Napoleon's forces attempted to attack. As a result, Napoleon's troops trekked deeper into Russia despite being ill-prepared for an extended campaign. In September, both sides suffered heavy casualties in the indecisive Battle of Borodino. Napoleon's forces marched on to Moscow, only to discover almost the entire population evacuated. Retreating Russians set fires across the city in an effort to deprive enemy troops of supplies. After waiting a month for a surrender that never came, Napoleon, faced with the onset of the Russian winter, was forced to order his starving, exhausted army out of Moscow. During the disastrous retreat, his army suffered continual harassment from a suddenly aggressive and merciless Russian army. Of Napoleon's 600,000 troops who began the campaign, only an estimated 100,000 made it out of Russia.

At the same time as the catastrophic Russian invasion, French forces were engaged in the Peninsular War (1808-1814), which resulted in the Spanish and Portuguese, with assistance from the British, driving the French from the Iberian Peninsula. This loss was followed in 1813 by the Battle of Leipzig [8], also known as the Battle of Nations, in which Napoleon's forces were defeated by a coalition that included Austrian, Prussian, Russian and Swedish troops. Napoleon then retreated to France, and in March 1814 coalition forces captured Paris.

On April 6, 1814, Napoleon, then in his mid-40s, was forced to abdicate the throne. With the Treaty of Fontainebleau, he was exiled to Elba, a Mediterranean island off the coast of Italy. He was given sovereignty over the small island, while his wife and son went to Austria.

\section{Hundred Days Campaign and Battle of Waterloo}

On February 26, 1815, after less than a year in exile, Napoleon escaped Elba and sailed to the French mainland with a group of more than 1,000 supporters. On March 20, he returned to Paris, where he was welcomed by cheering crowds. The new king, Louis XVIII (1755-1824), fled, and Napoleon began what came to be known as his Hundred Days campaign. Upon Napoleon's return to France, a coalition of allies-the Austrians, British, Prussians and Russians-who considered the 
French emperor an enemy began to prepare for war. Napoleon raised a new army and planned to strike preemptively, defeating the allied forces one by one before they could launch a united attack against him.

In June 1815, his forces invaded Belgium, where British and Prussian troops were stationed. On June 16, Napoleon's troops defeated the Prussians at the Battle of Ligny. However, two days later, on June 18, at the Battle of Waterloo [9] near Brussels, the French were crushed by the British, with assistance from the Prussians. On June 22, 1815, Napoleon was once again forced to abdicate.

\section{Napoleon's Final Years}

In October 1815, Napoleon was exiled to the remote, British-held island of Saint Helena, in the South Atlantic Ocean. He died there on May 5, 1821, at age 51, most likely from stomach cancer. (During his time in power, Napoleon often posed for paintings with his hand in his vest, leading to some speculation after his death that he had been plagued by stomach pain for years.) Napoleon was buried on the island despite his request to be laid to rest "on the banks of the Seine, among the French people I have loved so much." In 1840, his remains were returned to France and entombed in a crypt at Les Invalides in Paris, where other French military leaders are interred.

\section{Successes of Napoleon Bonaparte}

\section{Various Reforms:}

Napoleon instituted various reforms, such as higher education, a tax code, road and sewer systems, and established the Banque de France, the first central bank in French history. He negotiated the Concordat of 1801 with the Catholic Church, which sought to reconcile the mostly Catholic population to his regime. The Concordat of 1801 was an agreement between Napoleon and Pope Pius VII, signed on 15 July 1801 in Paris [10]. It remained in effect until 1905. It sought national reconciliation between revolutionaries and Catholics and solidified the Roman Catholic Church as the majority church of France, with most of its civil status restored. The hostility of devout Catholics against the state had then largely been resolved. It did not restore the vast church lands and endowments that had been seized upon during the revolution and sold off. Catholic clergy returned from exile, or from hiding, and resumed their traditional positions in their traditional churches. Very few parishes continued to employ the priests who had accepted the Civil Constitution of the Clergy of the Revolutionary regime. While the Concordat restored much power to the papacy, the balance of church-state relations tilted firmly in Napoleon's favour. He selected the bishops and supervised church finances [11].Napoleon and the pope both found the Concordat useful. Similar arrangements were made with the Church in territories controlled by Napoleon, especially Italy and Germany [12]

He dissolved the Holy Roman Empire prior to German Unification later in the 19th century. The sale of the Louisiana Territory to the United States doubled the size of the United States [13].

In May 1802, he instituted the Legion of Honour, a substitute for the old royalist decorations and orders of chivalry, to encourage civilian and military achievements; the order is still the highest decoration in France [14].

\section{Napoleonic Code}

Napoleon's set of civil laws, the Code Civil-now often known as the Napoleonic Code-was prepared by committees of legal experts under the supervision of Jean Jacques Régis de Cambacérès, the Second Consul. Napoleon participated actively in the sessions of the Council of State that revised the drafts. The development of the code was a fundamental change in the nature of the civil law legal system with its stress on clearly written and accessible law. Other codes ("Les cinq codes") were commissioned by Napoleon to codify criminal and commerce law; a Code of Criminal Instruction was published, which enacted rules of due process [15]. The Napoleonic code was adopted throughout much of Continental Europe, though only in the lands he conquered, and remained in force after Napoleon's defeat. Napoleon said: "My true glory is not to have won forty battles ... Waterloo will erase the memory of so many victories. ... But ... what will live forever is my Civil Code". The Code influences a quarter of the world's jurisdictions such as that of in Continental Europe, the Americas and Africa.

Dieter Langewiesche described the code as a "revolutionary project" which spurred the development of bourgeois society in Germany by the extension of the right to own property and acceleration towards the end of feudalism. Napoleon reorganized what had been the Holy Roman Empire, made up of more than a thousand entities into a more streamlined 
forty-state Confederation of the Rhine; this provided the basis for the German Confederation and the unification of Germany in 1871[16].

The movement toward national unification in Italy was similarly precipitated by Napoleonic rule. These changes contributed to the development of nationalism and the nation state [17].

Napoleon implemented a wide array of liberal reforms in France and across Continental Europe, especially in Italy and Germany, as summarized by British historian Andrew Roberts:

The ideas that underpin our modern world-meritocracy, equality before the law, property rights, religious toleration, modern secular education, sound finances, and so on-were championed, consolidated, codified and geographically extended by Napoleon. To them he added a rational and efficient local administration, an end to rural banditry, the encouragement of science and the arts, the abolition of feudalism and the greatest codification of laws since the fall of the Roman Empire [18].

Napoleon directly overthrew feudal remains in much of western Continental Europe. He liberalized property laws, ended seigneurial dues, abolished the guild of merchants and craftsmen to facilitate entrepreneurship, legalised divorce, closed the Jewish ghettos and made Jews equal to everyone else. The Inquisition ended as did the Holy Roman Empire. The power of church courts and religious authority was sharply reduced and equality under the law was proclaimed for all men [19].

\section{Warfare Policy}

In the field of military organization, Napoleon borrowed from previous theorists such as Jacques Antoine Hippolyte, Comte de Guibert, and from the reforms of preceding French governments, and then developed much of what was already in place. He continued the policy, which emerged from the Revolution, of promotion based primarily on merit [20]. Corps replaced divisions as the largest army units, mobile artillery was integrated into reserve batteries, the staff system became more fluid and cavalry returned as an important formation in French military doctrine. These methods are now referred to as essential features of Napoleonic warfare. Though he consolidated the practice of modern conscription introduced by the Directory, one of the restored monarchy's first acts was to end it [21]..

His opponents learned from Napoleon's innovations. The increased importance of artillery after 1807 stemmed from his creation of a highly mobile artillery force, the growth in artillery numbers, and changes in artillery practices. As a result of these factors, Napoleon, rather than relying on infantry to wear away the enemy's defenses, now could use massed artillery as a spearhead to pound a break in the enemy's line that was then exploited by supporting infantry and cavalry. Mc Conachy rejects the alternative theory that growing reliance on artillery by the French army beginning in 1807 was an outgrowth of the declining quality of the French infantry and, later, France's inferiority in cavalry numbers. Weapons and other kinds of military technology remained static through the Revolutionary and Napoleonic eras, but 18th-century operational mobility underwent change. Napoleon's biggest influence was in the conduct of warfare. Antoine-Henri Jomini explained Napoleon's methods in a widely used textbook that influenced all European and American armies. Napoleon was regarded by the influential military theorist Carl von Clausewitz as a genius in the operational art of war, and historians rank him as a great military commander. ${ }^{[239]}$ Wellington, when asked who the greatest general of the day was, answered: "In this age, in past ages, in any age, Napoleon".

Under Napoleon, a new emphasis towards the destruction, not just out maneuvering, of enemy armies emerged. Invasions of enemy territory occurred over broader fronts which made wars costlier and more decisive. The political effect of war increased; defeat for a European power meant more than the loss of isolated enclaves. Near-Carthaginian peaces intertwined whole national efforts, intensifying the Revolutionary phenomenon of total war [22].

\section{Metric system}

The official introduction of the metric system in September 1799 was unpopular in large sections of French society. Napoleon's rule greatly aided adoption of the new standard not only across France but also across the French sphere of influence. Napoleon took a retrograde step in 1812 when he passed legislation to introduce the mesures usuelles (traditional units of measurement) for retail trade[23] - a system of measure that resembled the pre-revolutionary units but were based on the kilogram and the metre; for example the livre metrique (metric pound) was $500 \mathrm{gl}$ instead of $489.5 \mathrm{~g}$-the value of the livre $d u$ roi (the king's pound)[24].Other units of measure were rounded in a similar manner prior to the definitive introduction of the metric system across parts of Europe in the middle of the 19th century [25]. 


\section{Education}

Napoleon's educational reforms laid the foundation of a modern system of education in France and throughout much of Europe. Napoleon synthesized the best academic elements from the Ancien Régime, The Enlightenment, and the Revolution, with the aim of establishing a stable, well-educated and prosperous society. He made French the only official language. He left some primary education in the hands of religious orders, but he offered public support to secondary education. Napoleon founded a number of state secondary schools (lycées) designed to produce a standardized education that was uniform across France. All students were taught the sciences along with modern and classical languages. Unlike the system during the Ancien Régime, religious topics did not dominate the curriculum, although they were present with the teachers from the clergy. Napoleon hoped to use religion to produce social stability [26]. He gave special attention to the advanced centers, such as the École Polytechnique, that provided both military expertise and state-of-the-art research in science [27] made some of the first efforts at establishing a system of secular and public education. The system featured scholarships and strict discipline, with the result being a French educational system that outperformed its European counterparts, many of which borrowed from the French system.

\section{The Failure or Downfall of Napoleon}

By 1808 , Napoleon was so dominant in France and in Europe that no one prophesized about his downfall. However between 1808-1815, there was resistance against Napoleon that made his downfall inevitable. The factors that led to the downfall of Napoleon [28] were both internal and external, long term and immediate, his own making and circumstances beyond his control as seen below;

\section{The continental system}

The continental system which was designed by Napoleon to defeat Britain became a boomerang that finally led to his own downfall.

- The system denied Europe, France inclusive the British cheap goods yet of high quality. Many people had to oppose his policy leading to his downfall.

- The system led to famine, unemployment, inflation, starvation and decline in international trade. These conditions undermined Napoleon's earlier achievements hence his downfall

- The continental system led to the formation of the $4^{\text {th }}$ and $5^{\text {th }}$ coalitions that defeated Napoleon. That is to say the $4^{\text {th }}$ coalition defeated Napoleon at the battle of Leipzig and imprisoned him at Elba. But Napoleon escaped and ruled for more 100 days. The $5^{\text {th }}$ coalition was formed that defeated Napoleon at the battle of Waterloo and Napoleon was imprisoned in the island of St. Hellena where he died in 1821.

- It made Napoleon impose heavy taxes to raise revenue to finance the continental system that was met with opposition

-Continental system made Napoleon to imprison the Pope hence loss of popularity especially from the Catholics

- It made Napoleon to get involved into peninsular war which he called the "Spanish ulcer that destroyed me"

- The continental system dragged Napoleon into the disastrous Moscow campaign where he lost over 580,000 troops.

- The system made Britain to spearhead and to mastermind most of the wars against Napoleon eg peninsular, $4^{\text {th }}, 5^{\text {th }}$ coalition etc

\section{Imprisonment of the Pope}

The continental systems made Napoleon to arrest and imprison the Pope. This was because the Pope complained bitterly about the side effects of the system over Rome, Italy and the entire Europe and he refused to implement it in the Papal States. Napoleon reacted by invading popal states, arrested the Pope and imprisoned him. This reduced his popularity among the Catholics in France and the whole Europe. This is why the alliance of catholic states like Austria, Prussia, Russia and Italy was formed against him hence his downfall

\section{The peninsular war (1808-1814)}


Napoleon's ambition to implement the continental system dragged him to the peninsular war which he called "an ulcer that destroyed me". The Portuguese and Spaniards turned and united against him at the battle of Trafalgar. This defeat proved to the world that Napoleon could be defeated, over 20,000 of his soldiers surrendered and it also weakened Napoleon's military strength. This led to the downfall of Napoleon in 1815

\section{The Moscow campaign (1812)}

The continental system entangled Napoleon into disastrous Moscow campaign which was the turning point in his military and political career in France and Europe. He experienced the heaviest military loss in the history of the world. It led to his downfall in that;

- He lost over 580,000 troops which weakened Napoleon military that is why he was defeated by the $4^{\text {th }}$ and $5^{\text {th }}$ coalitions

- European powers learnt that Napoleon was not untouchable, he could also be defeated

- It made a number of military officials to desert Napoleon. The heavy losses of the French soldiers, horses, conscription and over taxation forced Tallrand to join allied forces that defeated Napoleon

- The massive loss of 580,000 troops made Napoleon to resort to forceful recruitment, inexperienced, ill trained young men.

\section{The British Naval superiority}

Napoleon's lack of a strong navy relative to the British naval superiority led to his downfall. This explains why Napoleon was defeated at the battle of Trafalgar in 1805. By 1807, Napoleon had defeated nearly all European powers except Britain. This made Napoleon to;

- He had to resort to the continental system i.e. economic war to bring Britain to her knees

- The naval weakness partly accounts for the failure of the continental system

- It explains why Napoleon was defeated at the battle of Leipzig and Waterloo by the $4^{\text {th }}$ and $5^{\text {th }}$ coalitions. In these wars, Britain dominated mostly the sea

- All the wars fought against Napoleon were masterminded by Napoleon eg th $3^{\text {rd }}, 4^{\text {th }}, 5^{\text {th }}$ coalitions headed by Britain

- During the peninsular war, Britain took the advantage of her naval superiority to defeat Napoleon at the battle of Trafalgar

\section{Overwhelming ambition}

Napoleon was too ambitious and he wished to control the whole Europe. Napoleon's ambition could be gauged from his statement that "I have known the limits of my legs, I have known the limits of my eyes, I have never known the limit of my work." By 1812, he had forged the heterogeneous empire that was too big and too difficult to maintain by an individual. His ambition made him to fight endless wars. Its what made him to embark into the continental system which made his downfall inevitable by 1815 .

\section{The rise of European nationalism}

The rise and growth of nationalism undermined Napoleon's effort to dominate Europe. Napoleon had sown seeds of nationalism by preaching the French revolutionary ideas of equality, liberty and fraternity. However, he contradicted his preaching by over taxing people in the conquered popal states. His attempt to create Bonaparte family rule (Bonapartism) over Europe made him very unpopular in Europe e.g. he imposed his brother Joseph Bonaparte in Spain, Louis Bonaparte in Holland and Jerome Bonaparte in West Phalia. Napoleon was seen as fooling Europe and this led to the rise of Nationalism leading to his downfall

\section{The endless wars}

Throughout his career, Napoleon was involved in several wars that greatly contributed to his downfall. In the process of fighting many wars, the quality and quantity of his army deteriorated (declined) and his military ability to fight against opponents reduced. Its true that Napoleon fought 60 battles (differently) and emerged victorious in 49 . But the quality and quantity of his army declined that is why he was defeated at the battle of Trafalgar, Leipzig and Waterloo. In the peninsular 
war, he lost 300,000 , Moscow campaign 580,000 troops. He resorted to recruiting young boys of below 15 years and these ones could easily surrender to the opponents hence his defeat and downfall

\section{His old age}

By 1814, Napoleon had completely lost his sense of judgment due to brain depreciation that contributed to his downfall. Napoleon had fought too many wars to the extent that at the age of 45 years only, he appeared too old and exhausted. He was no longer capable of making proper judgment and planning. This is why he failed to foresee winter in Russia and he also foolishly relied on food from Russia during the peninsular war which actually made him to be defeated. His failure to use the former warfare and resorted to new tactics that led to his defeat at Leipzig and waterloo hence his downfall

\section{Economic decline in France}

By 1815, the French economy had declined. The revolutionary and Napoleonic wars drained the French resources and caused socio-economic problems like industrial breakdown, unemployment, inflation, famine and starvation. Besides, the wars had isolated France from the rest of Europe. It made France unable to finance, arm, train and pay her soldiers which affected their performance and led to the defeat of Napoleon by the allied powers. This was made worse when Napoleon imposed heavy taxes in order to maintain his large army making him unpopular hence his downfall

\section{The role of Britain}

Britain played a very crucial role towards the downfall of Napoleon Bonaparte. She had the strongest economy, superior naval force, and she was the force behind the formation of all coalitions that were formed against Napoleon and France at large. It was the British navy that defeated Napoleon in the battle of Trafalgar. The need to defeat Britain dragged Napoleon into the continental system. The British supported and allied with states like Italy and German as such support gave them courage to resist Napoleon's rule and rise of nationalism. All these contributed to the downfall of Napoleon

\section{Concert of Europe}

Lastly, the alliance of Europe against Napoleon finally contributed to his downfall. Napoleon in his military career was never defeated by a single power. But when the European powers combined their resources and armies in the $4^{\text {th }}$ coalition, it became too much for him to withstand and he was consequently defeated when he escaped from Elba, he ruled for 100 days and the $5^{\text {th }}$ coalition was formed that defeated him.

\section{Conclusion}

Finally we can say that Napoleon Bonaparte was a legend in the European history for his works. But St Helena, Napoleon said," Waterloo will erase the memory of all my victories". He was wrong. For better or erase, he is best remembered as a general and a military genius, not for his enlightened government. Napoleon worked to restore stability to post-revolutionary France. He centralized the government; instituted reforms in such areas as banking and education; supported science and the arts; and sought to improve relations between his regime and the pope (who represented France's main religion, Catholicism), which had suffered during the revolution. One of his most significant accomplishments was the Napoleonic Code, which streamlined the French legal system and continues to form the foundation of French civil law to this day.

\section{References}

[1] Charles Messenger, ed. (2001), Readers Guide to Military History Rutledge pp.391-427.ISBN 978-1-135-950708.

[2] Thompson. J.M. ed. The French Revolution: Documents, 1789-94(1948) pp.247.

[3] Reign of Terror, Encyclopedia Britannica (2015) Retrieved 19 April, 2017.

[4] Smith, The Greenhill Napoleonic Wars Data Book, Greenhill Books, 1998, p.140.

[5] Asprey, Robert B. The Rise of Napoleon Bonaparte, 604 pages, ISBN 0-465-04881-1.

[6] Loueisiana Purchase | History, Facts \& Map, Encyclopedia Britannica. Retrieved 2017-07-21.

[7] Napoleonic Wars, Westpoint .edu. U.S. Army. Retrieved 1 July 2017.

[8] Chandler, David G.(1966), The Campaigns of Napoleon, The Macmillan Company.p.134.

[9] Barbero. Alessandro (2005), The Battle: A New History of Waterloo. Atlantic Books, ISBN 1-84354-310-9. 
[10] Knight, Charles. "Pius VII," Biography: Or, Third Division of "The English Encyclopedia", Vol. 4, Bradbury, Evans \& Company, 1867 .

[11] Aston, Nigel. Religion and revolution in France, 1780-1804 (Catholic University of America Press, 2000) pp 279335.

[12] Roberts, William. "Napoleon, the Concordat of 1801, and Its Consequences", Controversial Concordats: The Vatican's Relations with Napoleon, Mussolini, and Hitler, (Frank J. Coppa ed.), (1999) pp: 34-80.

[13] Aston, Nigel. Christianity and revolutionary Europe, 1750-1830 (Cambridge University Press, 2002) pp 261-62.

[14] Blaufarb, Rafe (2007). Napoleon: Symbol for an Age, A Brief History with Documents. Bedford. ISBN 0-31243110-4.

[15] Geoffrey Marshall, "Due Process in England", in Nomos XVIII: Due Process, eds. J. Roland Pennock \& John W. Chapman, 69-92 (New York: New York University Press, 1977), 69.

[16] MC Graw Hill'S US History, 2012,pp 112-113.

[17] Knight, Charles, 'Pius. Mclynn, Frank(1998), Nepoleon pimlico. ISBN 0-7126-6247-2.ASIN 0712662472.

[18] Andrew Robert, Napoleon :A life (2014) p xxxiii (232)

[19] Robert R. Palmer and Joel Colton, A History of the Modern World (New York: MC Graw Hill,1995) pp.428-29

[20] Archer, Christon I.; Ferris, John R.; Herwig, Holger H. (2002). World History of Warfare. University of Nebraska Press. ISBN 0-8032-4423-1.[p-397]

[21] Archer, Christon l.; Ferris, John R.; Herwig, Holger H. (2002). World History of Warfare. University of Nebraska Press. ISBN 0-8032-4423-1[p-400]

[22] Archer, Christon l.; Ferris, John R.; Herwig, Holger H. (2002). World History of Warfare. University of Nebraska Press. ISBN 0-8032-4423-1.p-404]

[23] Hallock, William, Wade, Herbert (1906), Outlines of the evolution of weights and measures and the metric system. London; The Macmillan Company,pp.66-69.

[24] Thierry Sabot (1october, 2000), The weights and measures of the Ancient Regime, historical genealogy, Retrieved 10 February 2011.

[25] O'Connor, J; Robertson, E F (2003). "The history of measurement". St Andrew's University. Retrieved 18 July 2008.

[26] Roberts, Andrew (2014). Napoleon: A Life. Penguin Group. ISBN 978-0-670-02532-9.

[27] Margaret Bradley, Scientific education versus military training: the influence of Napoleon Bonaparte on the École Polytechnique. Annals of science (1975) 32\#5pp.413-449.

[28] history of napoleon bonaparte.blogspot.com/2013/09/the-downfall-of napoleon.html. 